\title{
Political Determination of Human Nature in the Context of Rousseau ${ }^{1}$
}

\author{
MEHMET Ş. ÇAĞMAR \\ Philosophische Fakultät, Eberhard Karls Universität Tübingen, Bursagasse 1 D-72070 Tübingen, Deutschland \\ Department of Philosophy, Ankara University, Ankara, 06100, Turkey \\ Email:mcagmar@yahoo.com
}

\begin{abstract}
In this study, we will try to show that human nature can be handled with a political determination in Rousseau. Human nature has always been a controversial subject of political philosophy in the historical process. So much so that in these discussions we can see that human nature, especially with Rousseau, is now treated as something that is shaped and changed separately for each of various processes of history. Therefore we will first focus on how human nature is defined in Rousseau in the state of nature to show that human nature has been subjected to political influence in the historical process. Then we will examine how the human nature takes shape with the civilization leading to the end of the state of nature. Finally, through social contracting, we will focus on how human nature is transformed into a political thing by gaining a new dimension.
\end{abstract}

Keywords: human nature, natural state, civilization, social contract, political determination

\section{INTRODUCTION}

In this article we will examine the relationship between human nature and political structure. As is known, many discussions about human nature have been made in political philosophy debates. However, when we look at many of these discussions, it turns out that discourses on human nature are different from each other. The debate about human nature has maintained its position as a judge especially in the 18th century. Because the influence that the Renaissance and the reform movements initiated has brought together the French revolution and laid the groundwork for the emergence of political debates, and in these discussions human nature has become one of the defining or determined issues by the political sphere.

In these debates, human nature has been affected by political developments in the historical process, as in everything else, according to my claim. But the most important thing to focus here is whether or not human nature is affected by political developments, or whether human nature is undergoing a process of change and transformation, or, in other words, can human nature still remain unchanged in the face of political developments? What we are trying to dwell on in this article is to seek answers to these points.

1 I would like to thank Prof. Dr. Hamdi BRAVO, who gave me new ideas and helped me in the process of writing my article. 
Many thinkers agree that people have a nature. However, the basic point of all of them is that the nature of the human being remains unchanged. But Rousseau, unlike them, shows us that human nature has undergone a change, in fact, that it does not always remain the same in a nature state, in the civilization and social contract. Even though the human nature itself has undergone a change, the problem of how human nature becomes in the face of this change emerges. My main claim here is that human nature in Rousseau is shaped by the political structure together with the social contract in the last process.

According to Rousseau, at the beginning of the historical process people were in a state of nature. In this situation they have certain needs and they were in fact met by nature. Therefore, according to Rousseau, this period represents a period when man lived according to the requirements of his own nature. However, according to him, natural conditions have come to a compulsive condition in terms of things that necessitate human survival, and human nature has now taken its share from the enforcement. As a result, the notion of ownership emerged necessarily and the human civilization process started. Civilization refers to a process in which human relations begin. But human relations are to leave one's natural side in terms of Rousseau. Because, according to him, the civilization struggle of human beings has recorded the natural freedom as nature state through its attachment to human relations, but at the same time it has begun to lose its living condition according to the requirements of nature. For Rousseau, civilization needs to evolve into a political point. The way to do this is the Social Contract, which is something that everyone will be able to participate with their own will. According to him, with the contract, people have now moved away from the natural tendencies of nature to one side and become compatible with the entirely political structure due to socialization relations. Thus, in terms of Rousseau, people have become naturally compatible with this political structure, since they are connected to a political basis through the Social Contract and when the subject of the nature of the individual, he went to the point where he could not take it apart from the situation which is a political structure.

\section{NATURE STATUS}

According to Rousseau, in order to understand human nature, we first have to look into its state of nature. The state of nature refers to the way in which Rousseau lives in a way that conforms to the nature of man. In such a situation, there is no way of confronting anything that a person can limit himself. Rousseau therefore regards the state of nature as an area where man has the opportunity to live his own nature freely.

Unlike many thinkers who came before him, Rousseau treats man as a whole with nature in his natural state. According to him, human beings have various needs and meet these needs in nature. So Rousseau is defined as an entity integrated with nature by lifting the borders between man and nature. He expresses the situation in the nature of man in the following words:

'I see him satisfying the calls of hunger under an oak, and those of thirst at the first rivulet; I see him laying himself down to sleep at the foot of the same tree, that afforded him his meal; and behold, this done, all his wants are completely supplied' (Rousseau 1971: 17). Thus, within the context of the human Rousseau in the state of nature, certain basic needs are addressed and these needs can be defined as eating, drinking and marriage. Apart from these, what remains are not necessarily obligatory in nature. So much so that in a nature state a person does not even need a language (Rousseau 1971: 48-50). Because Rousseau is already meeting the human needs in the nature situation from nature. There is no need to communicate with other people who have the language ability. In terms of Rousseau, meeting 
the specific needs in the nature state is only for the needs that need to be satisfied at that moment. Nature also does not make an effort to postpone its needs because it provides them with the necessary facilities for it. Therefore, the individual does not need to use the intelligent ability to meet his needs (Charvet 1974: 9). Because there is nothing that restricts it in terms of its needs in the nature situation, it does not make any future or future planning. So, according to Rousseau, things that are physically needed in the state of nature are the only thing that both foreshadows and is necessary for man. According to Rousseau, in the state of nature, man has no more than what he needs as an asset indexed to natural needs, nor does he have to retain what he has in his possession and then meet his needs. Rousseau sees it as a minor asset in the nature, expressing that the human being has no dependency on his needs (Rousseau 1971: 92). Rousseau sees the reason for this in the harmony of man with nature. Because, according to him, in the state of nature, man is in harmony with himself and his surroundings (Warner 2015: 65). Therefore, the nature of existence reveals for Rousseau the existence of nature (Friedlander 2004: 19).

Adaptation of human beings in relation to nature necessitated some physical changes in the human body. Because if we look at Rousseau from the point of view of how human beings are in harmony with nature, this harmony is possible only if the person becomes suitable to the natural conditions. Therefore, the condition of maintaining the existence of man in harmony with nature can be achieved by having a characteristic that is suitable for natural conditions. In other words, according to Rousseau, man is not an entity that can sufficiently resist nature in nature with a purely bodily property. In order to be able to stand, the body must become suitable for various natural conditions (Rousseau 1971: 17).

Man's harmony with nature has not always continued. A certain place after, according to Rousseau, a certain shortage of nature has turned into growing man's insatiable needs led to the permanent allocation of land. This situation became increasingly unstable, and private property rights began to be used as a solution to the threat of an increase in civil war in an effort to regulate and secure the political peace of humanity (Wolker 2012: 100). From Rousseau's point of view, this situation has had important consequences. Because, first of all, the concept of property undermines a certain limitation in one aspect. On the other hand, it has allowed him to respect other people's limitations such as himself (Warner 2015: 72). Hence, human nature has begun to lose its state of limitlessness in the face of this situation and to move to a new stage which can be handled together with the relation of socialization.

Consequently, according to Rousseau, the state of nature has now come to be an area in which man can continue his life by leaving him to the usual conditions of nature. Because the opportunities that nature offers to him or that he cannot offer anymore force him to look into his own desperation in nature. Hence, human beings have now begun to develop a sense of ownership over certain areas/things by drawing their own boundaries. Thus, according to Rousseau, the first person to find a person so pure as to believe in him, who could say 'This is mine' by ringing around a piece of land, is the true founder of the civilized social (Rousseau 1971: 97).

\section{CIVILIZATION CRITICISM}

According to Rousseau, with the transition of civilization, man now finds himself faced with the embodiment of civilization. This means that for Rousseau, as a state of departure from nature, a human being is introduced into a mold through civilization of its natural orientation. While Rousseau is criticizing civilization, he tries to treat the person with a pure physical 
and spiritual power. Such handling is to uncover the natural direction of man in terms of it. But according to Rousseau, civilization has left one's natural side to one side. A concealment situation has been realized on the nature by putting the virtues that civilization brings. Because, according to him, all worthiness judgments that civilization brings have a function of concealing the natural side of man. This criticism that Rousseau has done is explained by his statements:

'A superb dress may opulence; an elegant one a man of taste; but the healthy and robust are known by different indications. It is under the rustic habit of a labourer, and not beneath the lace or embroidery of a courtier, that we should look for bodily strength and activity.

Exteriour ornaments are no less foreign to virtue, which is the stretch and activity of the mind. The man of probity is an athletic, who loves to combat his adversary naked; despising those pault trappings, which prevent the exertion of his strength, and were, for he most part, invented only to conceal some deformity' (Rousseau 1972: 8). Rousseau treats his state of freedom as a state of personal sensitivity we have developed to counter our existing form of alienation (Moraitis 2018: 235) and, according to him, a problem of freedom has arisen with the transition from the state of nature to civilization. To be free is to have nothing that the individual has to obey. In the state of nature, Rousseau defines the natural person as a free individual, since there is nothing that the individual has to adhere to. Rousseau's point of departure from freedom is to force the individual to stay within the framework of the molds of the things to which he is bound because of what he must obey. As civilized man, he has to obey various moral judgments, customs, rules ... etc. (Rousseau 1972: 7-8). Thus, these things which he has to adhere to cause him to lose the liberty of his own nature by forcing him to remain under the virtues of civilization (Allers 1958: 93). According to the civilized human Rousseau, it is a contrived attitude. Things that have brought their own nature have gone to disappear under the name of civilization. Instead of being replaced by their civilization as a virtue, these virtues have begun to be regarded as all herbs (Rousseau 1972: 8). Rousseau sees this situation as an attack on human nature, on the one hand, and, on the other hand, he sees the human being as a picture of the end of the possibility of living freely in its nature (Neuhouser 2014: 48). Because for him civilization has been forced to obey by something outside of man's nature, revealing himself as a corruption by ensuring a certain determination (Rousseau 1972: 9). According to Rousseau, the human being in nature has a very limited knowledge of the world. This limits the world of human knowledge to its own individuality. He does not need to know beyond that. Because, as we have mentioned above, it is sufficient for him to meet the compulsory needs of the natural person. Having more information is not something you need to get involved in your life. But with civilization, according to Rousseau, people have made a struggle to know more and have brought a disaster to themselves. This process of wretchedness is a violation of the wisdom in terms of Rousseau. The presence of people in an 'ignorance' is a limit to which wisdom has set. But people have begun a disaster in violation of this 'ignorance' limit that the wisdom has put it on. According to Rousseau, civilization does not treat man as it is in nature. It needs to be what it takes because it is an ideal for man. They force themselves to obey him. So according to Rousseau, a bad poet in his whole life could be a man who would remain a dull mathematician, maybe a big fabric factory. The people whom nature raised to raise apprentices did not need the skill (Rousseau 1972: 40). Although Rousseau criticizes a civilization, it also offers a solution. For him it is a situation that has negative aspects but people should be accepted as a transition to the civilization process. Because according to Rousseau, who realistically understands the period, it is 
no longer the case that we should return to nature. A different turn has come in the process. So, according to Rousseau, if we still act in the context of the nature state at this time, then we go to an extinction (Rousseau 1968: 59). What needs to be done now is to establish a political system based on partnership, in which everyone can be included on his own will, taking into account the circumstances of the time.

\section{CONSTRUCTION OF THE POLITICAL SYSTEM}

Rousseau distinguishes the historical process of mankind in two senses. As we mentioned above, the first period can be expressed as the state of nature in which people lead a life completely within the natural conditions and their individuality is dominant. The second period, however, refers to the shift of people from nature to social life. Nature has a natural mechanism that works within itself. However, socialization differs from nature in this way, bringing together problems such as how this partnership is to be built and on which bases relations between individuals should be established because each individual has his own individual wishes. Each of these requests remains a problem as to how they can be found in the common denominator. Rousseau's solution to such a problem is to take people as they are and bring them together in a framework of law (Rousseau 1968: 49).

According to Rousseau, the laws bring a social order. It is meaningless that we do not expect nature from this place because the order in nature is spontaneous as part of the natural process. It is something that cannot be disrupted by a human intervention, nor is it something that can be brought to the scene by a human process. But the social field is something we have as an artificial condition. So, according to Rousseau, we can find a structure in which we are going to seek social order, but rather to wait for the nature itself, but to become a definite agreement between ourselves (Rousseau 1968: 49). Thus Rousseau has made it possible, along with the social field, to be an entity that takes the individual from being an existing entity and contributes to the formation of order.

The provision of an order through contract from the societal area is a way of preventing people from living according to the conditions that nature brings. According to Rousseau, the situation of nature is a condition in which people do not need to come together and form sociality, but live a life with their own individual strength. That is why if we take everything as if nature is the case, we go to destruction (Rousseau 1968: 59). Because, according to Rousseau, all the individuals within social are prevented from attaining social partnership in their attempt to behave with their own individual strength.

Rousseau gives the name of the Social Contract to the partnership formed through the provision of an agreement in the social field and tries to express what this contract has to offer:

'How to find a form of association which will defend the person and goods of each member with the collective force of all, and under which each individual, while uniting himself with the others, obeys no one but himself, and remains as free as before. This is the Fundamental problem to which the social contract holds the solution' (Rousseau 1968: 60).

The Social Contract is the one for Rousseau that prevents the individual from being dominated by another individual in social and makes him equal to himself as the other individual. So what is essential to the contract is that, with everyone being equal, it is neither a burden to someone else nor a slave of someone else (Rousseau 1968: 58-59). Thus, for all this, Rousseau tries to show the Social Contract as an address to ensure that every individual has the idea of an equal social based on freedom to guarantee his autonomous individuality (Cohen 2010: 16). 
The individual, with the contract, now delivers all his individual powers to the general will. He begins to function as part of the indivisible unity of this general purpose. It loses its special character and acquires a legal personality (Rousseau 1968: 60-61). According to Rousseau, an individual may not always be in compliance with the contract of being a legal entity. Sometimes the interests that are presented as the general will of the social with his individual interests may be in conflict with each other. In such a case, the individual must leave his or her own interests to one side so that the contract is not violated. If individual interests are prioritized then they are forced to obey the interests that they have in general (Trachtenberg 2003: 214).

According to Rousseau, the instinct that the individual possesses in the nature of the state with the transition to the contract is no longer present. Their place takes the place of justice. Individuals tend to move away from their own physical impulses and tend to believe that partnership can be achieved within the concept of law for sociality. It therefore becomes a restrained entity in the face of things that have evolved from one's own nature. In the face of a tendency that he wishes to pursue, the natural nudism of the individual is now in flux and begins to determine the guidance of the mind as a pioneer in order to realize its natural tendencies. Rousseau tries to express this with the following words:

'The passing from the state of nature to the civil social produces a remarkable change in man; it puts justice as a rule of conduct in the place of instinct, and gives his actions the moral quality they previously lacked. It is only then, when the voice of duty has taken the place of physical impulse, and right that of desire, that man, who has hilberto thought only of himself, finds himself compelled to act on other principles, and to consult his reason rather than study his inclinations. And although in çivil social man surrenders some of the advantages that belong to the state of nature, he gains in return far greater ones; his faculties are so exercised and developed, his mind is so enlarged, his sentiments so ennobled, and his whole spirit so elevated that, if the abuse of his new condition did not in many cases lower him to something worse than what he had left, he should constantly bless the happy hour that lifted him for ever from the state of nature and from a stupid, limited animal made a creature of intelligence and a man' (Rousseau 1968: 64-65).

In this respect, according to Rousseau, the individual has lost his natural freedom and the desire to obtain unlimitedly everything that attracts him. What he earns, however, is the civil liberty and possession (Rousseau 1968: 65). According to him, the natural judgments have gone to extinction as it is possible within the framework of a political structure and these judges are now left as political judges (Inston 2010: 23).

\section{FINAL REMARKS}

In this article we examined the relationship between human nature and political structure in the context of Rousseau. The framework we have drawn for this was primarily the human design in the state of nature. It is then how this person has affected the nature of the process of civilization which he lived with the socialization. Finally, it has been the consideration of how the socialized man, along with the political structure, affects his nature.

Under a situation where there is no political structure, human nature does not have any structure that will interfere with itself. However, if this state is valid in a state where there is no political period, it would reveal that there was a period in which there was no political structure. If we try to answer such a question through Rousseau, he has transitioned from the nature to the political status in the historical process. Therefore, we will also be able to understand his nature through this trace which forms the boundaries of our discussion. 
We observe that Rousseau treats the historical process of man in two general periods in general terms. These are (1) the state of nature and (2) the construction of the political sphere together with the Social Contract. This distinction can also be expressed as the period when the human being is in fact acting according to the nature and the period when his nature is under the pressure of the political field. Because for Rousseau there is a series of external conditions that influence the transition from human nature to contract. However, these external conditions make it possible for a change in the internal conditions of the human being. The inner conditions here indicate the nature of man in terms of Rousseau.

In the state of nature Rousseau sees man's nature as an area where he can live freely. However, even if they are defined as a field of freedom, it is necessary to look at the dependency of people at this time. For Rousseau, people meet their needs from nature at this time. Freedom is becoming controversial if we take into account the dependence of this person on their needs. Because at this time Rousseau defines freedom as a human being under the yoke of nature. Nature does not offer that you do not want to offer what you want. Therefore we can say that human nature is not in a pure state of being in this period and as our basic argument for the state of nature is that we can lead the human nature, that nature is something that can only be understood by what nature gives us.

In Rousseau, with the transition to the political arena, human beings are no longer treated as freedom in the state of nature, which expresses the end of the state of nature- the beginning of the formation of a sociality. For Rousseau, the fact that people are not treated like this is actually an opportunity for the construction of the political sphere. For there is no possibility that the freedom and the political structure of nature exist at the same moment. Rousseau, however, sees liberty in the state of nature as something to be left aside from the construction of the political structure, but Rousseau does not try to remove freedom altogether.

Rousseau deals with freedom in two ways. First, liberty in the form of nature can be defined as freedom in the political space through contract. As mentioned above, the province expresses the freedom of the individual in nature. The second, however, is a liberty within Rousseau's political structure, which is the result of a compulsory socialization of the individuals. Rousseau is struggling to provide the second form of freedom since it is not possible to achieve the first liberation in the process.

Freedom is handled in Rousseau in relation to human nature. When we consider this relationship in terms of nature in Rousseau, freedom means living in a way that conforms to the nature of man. However, with the agreement, freedom has evolved for Rousseau to something that is now understood to be shaped by the political nature of human nature. Hence the human nature, which Rousseau dealt with the transition from the state of nature to the social contract, has now transformed into something to be defined under the influence of the political structure and initiated new debates for the field of contemporary political philosophy. Thus, as a result, we can say that human nature undergoes political determination.

Received 1 May 2018

Accepted 20 May 2019

\section{References}

1. Allers, U. S. 1958. 'Rousseau's Second Discourse', The Review of Politics 20(1): 91-120.

2. Charvet, J. 1974. The Social Problem in the Philosophy of Rousseau. Oxford: Oxford University Press.

3. Cohen, J. 2010. Rousseau: A Free Community of Equals. New York: Oxford University Press.

4. Friedlander, E. 2004. J. J. Rousseau: An Afterlife of Words. London: Harvard University Press.

5. Inston, K. 2010. Rousseau and Radical Democracy. New York: Continuum Press. 
6. Moratis, Y. 2018. 'Openness, Relativity and the Radical Force of Jean-Jacques Rousseau's Democratic Theory', Journal of Human Values 24(3): 232-237.

7. Neuhouser, F. 2014. Rousseau's Critique of Inequality Reconstructing the Second Discourse. Cambridge: Cambridge University Press.

8. Rousseau, J. J. 1971. A Discourse upon the Origin and Foundation of the Inequality among Mankind. New York: Lenox Hill Press.

9. Rousseau, J. J. 1972. Miscellaneous Works of J. J. Rousseau I. New York: Lenox Hill Press.

10. Rousseau, J. J. 1968. The Social Contract. London: Penguin Press.

11. Trachtenberg, Z. M. 1993. Rousseau's Political Theory of Culture. New York: Routledge Press.

12. Warner, J. M. 2015. Rousseau and the Problem of Human Relations. Pennsylvania: Penn State University Press.

13. Wolker, R. 2012. Rousseau, the Age of Enlightenment, and Their Legacies. Oxford: Princeton University Press.

\title{
Politinis žmogaus prigimties determinavimas J. J. Rousseau darbuose
}

\begin{abstract}
Santrauka
J. J. Rousseau darbuose žmogaus prigimtis neatsiejama nuo politinio determinavimo. Istoriniame procese žmogaus prigimtis visada buvo prieštaringas politinès filosofijos objektas. Apžvelgiant diskusijas išryškejja, kad žmogaus prigimtis, ypač J. J. Rouseau darbuose, traktuojama kaip kažkas, kas formuojama ir keičiama nepaisant ịvairių istorijos procesų. Todèl pirmiausia sutelkiamas dèmesys ị žmogaus prigimtị natūralioje valstybèje, siekiama parodyti, kad žmogaus prigimtis priklauso nuo politinès įtakos istoriniame procese. Vèliau analizuojama, kaip žmogaus prigimtis keičiasi kartu su civilizacija, kuri veda ị natūralią valstybę. Galiausiai, remiantis socialine sutartimi, sutelkiamas demesys ị tai, kaip žmogaus prigimtis pakeičiama ị politinị diskursą, kuris iggauna naują dimensiją.
\end{abstract}

Raktažodžiai: žmogaus prigimtis, natūrali valstybè, civilizacija, socialinė sutartis, politinis determinavimas 